\title{
The polyenic system of retinyl phosphate is required for its mannosyl donor activity but not for acceptor activity
}

\author{
Yoshihiro SHIDOJI, Carol S. SILVERMAN-JONES and Luigi M. DE LUCA* \\ Differentiation Control Section, Building 37, Room 3A-17, National Cancer Institute, Bethesda, MD 20205, \\ U.S.A.
}

(Received 5 August 1982/Accepted 4 October 1982)

\begin{abstract}
We investigated whether the polyenic and allylic phosphate systems of retinyl phosphate are essential for its mannosyl acceptor and donor activities in rat liver postnuclear membranes. Perhydromonoeneretinyl phosphate, a compound without growth-promoting activity in vitamin A-deficient animals, was prepared by catalytic hydrogenation of retinol and phosphorylation. Perhydromonoeneretinyl phosphate mannose synthesis from GDP-mannose showed continued accumulation for at least $60 \mathrm{~min}$, while retinyl phosphate mannose synthesis showed a maximum at 20-30 min and then declined. Moreover, only retinyl phosphate stimulated transfer of mannose from GDP-mannose to endogenous proteins, which were separated by sodium dodecyl sulphate/polyacrylamide-gel electrophoresis. Thus, hydrogenation of side-chain double bonds in retinyl phosphate impaired only slightly its mannosyl acceptor activity, but caused loss of mannosyl donor activity.
\end{abstract}

Ret- $P$ accepts mannose from GDP-mannose to form Ret- $P$-Man in a reaction catalysed by mammalian microsomal membranes (De Luca, 1977). Further, phosphorylation of the vitamin has been shown in intestinal cells (Frot-Coutaz et al., 1976) and endogenous Ret- $P$ was demonstrated in rat liver microsomes (De Luca et al., 1982), using a recently developed incubation mixture containing BSA (Shidoji \& De Luca, 1981).

We now ask whether the polyenic and allylic phosphate systems of Ret-P are necessary for its mannosyl acceptor and donor activities. pRet-P (structure shown below) was synthesized and utilized for this purpose.

\section{Materials and methods}

\section{Materials}

Bovine serum albumin and GDP-mannose were from Sigma; Millipore filters (HA; pore size $0.45 \mu \mathrm{m}$ )

\footnotetext{
* To whom reprint requests and correspondence should be sent.

Abbreviations: Ret- $\boldsymbol{P}$-Man, retinyl phosphate mannose; pRet- $P$-Man, perhydromonoeneretinyl phosphate mannose; Dol-P-Man, dolichyl phosphate mannose; Ret- $P$, retinyl phosphate; $\mathrm{pRet}-P$, perhydromonoeneretinyl phosphate; Dol- $P$, dolichyl phosphate; BSA, bovine serum albumin; DTT, dithiothreitol; SDS, sodium dodecyl sulphate; medium A, $50 \mathrm{~mm}-\mathrm{Tris} / \mathrm{HCl}$ buffer, $\mathrm{pH} 7.6$, containing $5 \mathrm{mM}-\mathrm{MgCl}_{2}, 25 \mathrm{mM}-\mathrm{KCl}$ and $0.25 \mathrm{M}$-sucrose.
}

Vol. 208

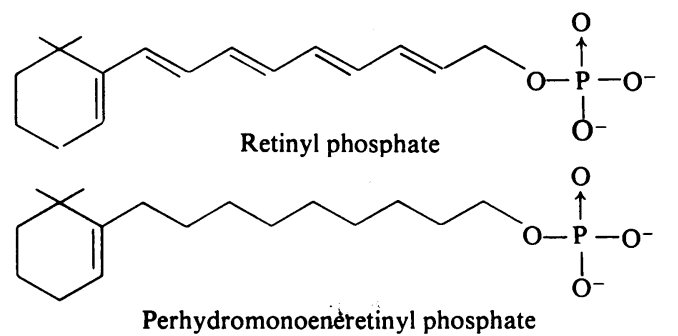

were from Millipore, Boston, MA, U.S.A. Ret- $P$ was synthesized by chemical phosphorylation (Bhat et $a l ., 1980)$ and pRet- $P$ was made by catalytic hydrogenation of retinol (De Luca et al., 1977) followed by chemical phosphorylation. GDP- $\left[{ }^{3} \mathrm{H} \mid\right.$ mannose (sp. radioactivity $10 \mathrm{Ci} / \mathrm{mmol}$ ) and $\mathrm{GDP}-\left[{ }^{14} \mathrm{C} / \mathrm{man}\right.$ nose (sp. radioactivity $0.2 \mathrm{Ci} / \mathrm{mmol}$ ) were obtained from New England Nuclear Corp., Boston, MA, U.S.A.

\section{Preparation of rat liver postnuclear membranes}

Male rats (Osborne-Mendel strain), weighing $150-200 \mathrm{~g}$, were starved overnight and killed by bleeding under light diethyl ether anaesthesia. The livers were homogenized with 2 vol. of medium A with a glass/Teflon homogenizer. After centrifugation at $2500 \mathrm{~g}$ for $20 \mathrm{~min}$, the resultant supernatant was centrifuged at $105000 \mathrm{~g}$ for $60 \mathrm{~min}$. The pellet was resuspended in medium $A$ and kept in liquid $\mathrm{N}_{2}$ until use. 


\section{Mannosylation of endogenous acceptors}

The incubation mixture contained the following constituents at the indicated final concentrations: $30 \mathrm{~mm}$-Tris $/ \mathrm{HCl}$ buffer, $\mathrm{pH} 8.0 ; 4 \mathrm{mg}$ of $\mathrm{BSA} / \mathrm{ml}$; $2.5 \mathrm{mM}-\mathrm{MnCl}_{2} ; 8 \mathrm{mM}-\mathrm{NaF} ; 4 \mathrm{~mm}-\mathrm{ATP} ; 5 \mathrm{~mm}$-AMP; $0.4 \mu \mathrm{Ci}$ of GDP- $\left[{ }^{3} \mathrm{H}\right]$ mannose (GDP-mannose was added to final concentration of $24 \mu \mathrm{M}$ ); and $1 \mathrm{mg}$ of rat liver microsomal protein in $200 \mu$ l final volume. Incubation was at $37^{\circ} \mathrm{C}$ in the presence or absence of either exogenous Ret- $P$ or pRet- $P$ (final concentration $0.15 \mathrm{mM}$ ). The reaction was stopped by the addition of $1 \mathrm{ml}$ of ice-cold medium $\mathrm{A}$ and the resultant solution was immediately poured on to a Millipore filter (HA; $0.45 \mu \mathrm{m}$ ) to trap microsomal membranes. An additional $1 \mathrm{ml}$ of ice-cold medium $A$ was added to wash out the unchanged GDP$\left[{ }^{3} \mathrm{H}\right]$ mannose. The washed damp filter was placed into a counting vial that contained $5 \mathrm{ml}$ of chloroform/methanol $(2: 1, \mathrm{v} / \mathrm{v})$, and was kept at room temperature for $1 \mathrm{~h}$. Then the filter paper was transferred to another counting vial and the chlorofom/ methanol $[2: 1, \mathrm{v} / \mathrm{v},(5 \mathrm{ml})]$ extraction was repeated twice more. The combined extract was evaporated to dryness and the radioactivity was counted in $10 \mathrm{ml}$ of Betafluor. After washing the filter twice with $5 \mathrm{ml}$ of water, it was immersed in $5 \mathrm{ml}$ of chloroform/methanol/water $(10: 10: 3$, by vol. $)$ in a counting vial. This process was repeated twice. The radioactivity in the total chloroform/methanol/water $(10: 10: 3$, by vol.) fraction was counted in $10 \mathrm{ml}$ of Betafluor after removing the solvent. The residual radioactivity retained on the filter was extracted by Protosol (New England Nuclear, Boston, MA, U.S.A.) treatment; $50 \mu \mathrm{l}$ of Protosol was added to a filter and the vial was incubated at $50^{\circ} \mathrm{C}$ overnight in $10 \mathrm{ml}$ of Betafluor.

Ret- $P$-Man and pRet- $P$-Man were analysed by t.l.c. The extract was applied to a silica-gel thin-layer plate (F-254; Merck) and developed in chloroform/ methanol/water $(45: 35: 6$, by vol.). The silica gel $(0.5 \mathrm{~cm}$ sections) was scraped into counting vials and the radioactivity was determined after addition of $0.25 \mathrm{ml}$ of methanol and $10 \mathrm{ml}$ of Betafluor (National Diagnostics, Sommerville, NJ, U.S.A.). Alternatively the filtration assay was employed as described by Shidoji \& De Luca (1981).

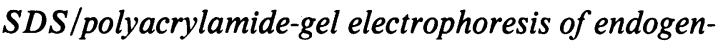 ous mannose acceptors}

The procedure of Shimatake \& Rosenberg (1981) was followed to build a gradient gel from 10 to $26 \%$ acrylamide, closely fashioned after the procedure of Laemmli (1970).

\section{Other procedures}

Protein was determined by the method of Lowry et al. (1951) with BSA as standard. Ret- $P$ was measured spectrophotometrically at $325 \mathrm{~nm}$ in methanol $\left(\varepsilon_{1 \mathrm{~cm}}^{1 \%}=1440 \mathrm{M} \cdot \mathrm{cm}^{-1}\right)$. The concentration of Ret- $P$ was determined by measurement of the phosphate content by the procedure of Chen et al. (1956).
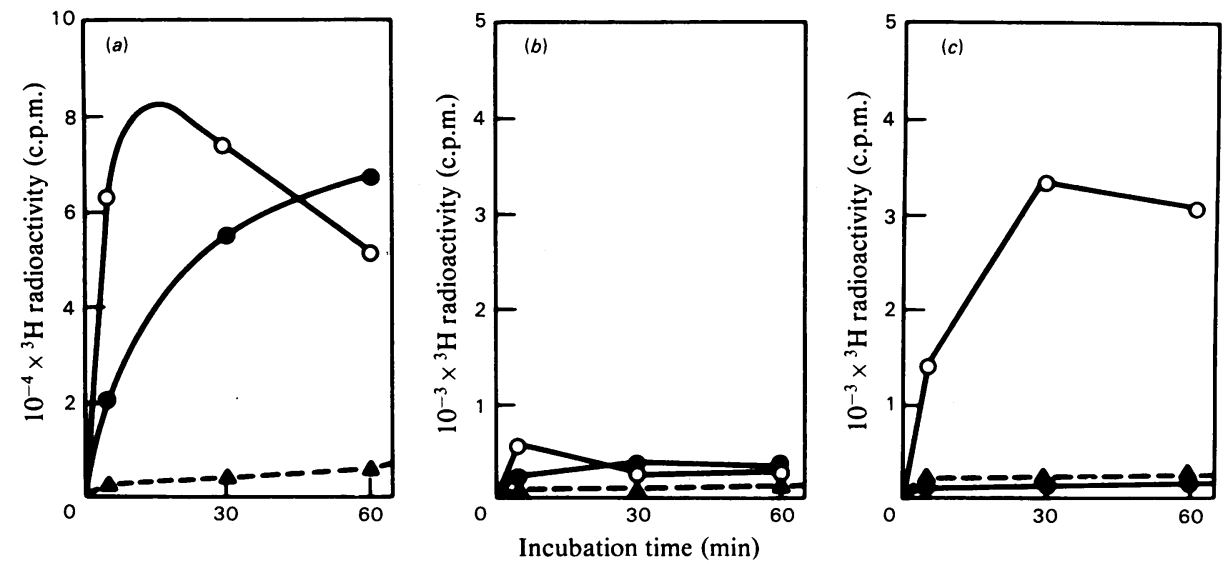

Fig. 1. Comparison of Ret-P and pRet-P in mannosylation reactions of rat liver microsomes GDP- $\left[{ }^{3} \mathrm{H}\right]$ mannose $(0.4 \mu \mathrm{Ci} ; 24 \mu \mathrm{M})$ was incubated at $37^{\circ} \mathrm{C}$ with rat liver microsomes $(1.5 \mathrm{mg}$ of protein) in the absence $(\Delta)$ or presence of $1.15 \mathrm{~mm}$-Ret-P $(0)$ or - pRet- $P(\Theta)$. After incubation, the membrane vesicles were collected by Millipore filter and extracted sequentially with $5 \mathrm{ml}$ of chloroform/methanol $(2: 1, \mathrm{v} / \mathrm{v})$ three times, $5 \mathrm{ml}$ of water twice and $5 \mathrm{ml}$ of chloroform/methanol/water $(10: 10: 3)$ twice and the residues were digested with $50 \mu \mathrm{l}$ of Protosol at $50^{\circ} \mathrm{C}$ overnight. Each point represents an average of duplicate incubations differing by less than $15 \% .(a),(b)$ and (c) show results after chloroform/methanol extraction, chloroform/methanol/water extraction and Protosol digestion respectively. 


\section{Results and discussion}

These experiments were specifically designed to study the requirement of the polyenic and allylic phosphate systems in Ret- $P$ for its mannosyl acceptor and donor activity in postnuclear membrane of rat liver.

For this purpose retinol was hydrogenated catalytically to produce perhydromonoeneretinol, which was then phosphorylated. This compound was inactive in promoting growth of vitamin A-deficient hamsters (Y. Shidoji, C. S. Silverman-Jones \& L. M. De Luca, unpublished work).
Several striking differences between Ret- $P$ and pRet- $P$ were noted. Time-course studies showed an accumulation of pRet-P-Man (Fig. 1), whereas Ret- $P$-Man reached a maximum at about $30 \mathrm{~min}$ and then decreased, suggesting an intermediary function of this compound and/or hydrolysis.

Most (65-80\%) of the radioactivity in the chloroform/methanol $(2: 1, \mathrm{v} / \mathrm{v})$ extract co-migrated with standard Ret- $P$-Man, whereas pRet- $P$-Man showed a slightly more hydrophobic (higher $R_{F}$ ) behaviour on t.l.c. This transfer did not occur in incubations containing amphomycin, which inhibits Ret-P-Man synthesis (Shidoji \& De Luca, 1981). Unlike Dol-P

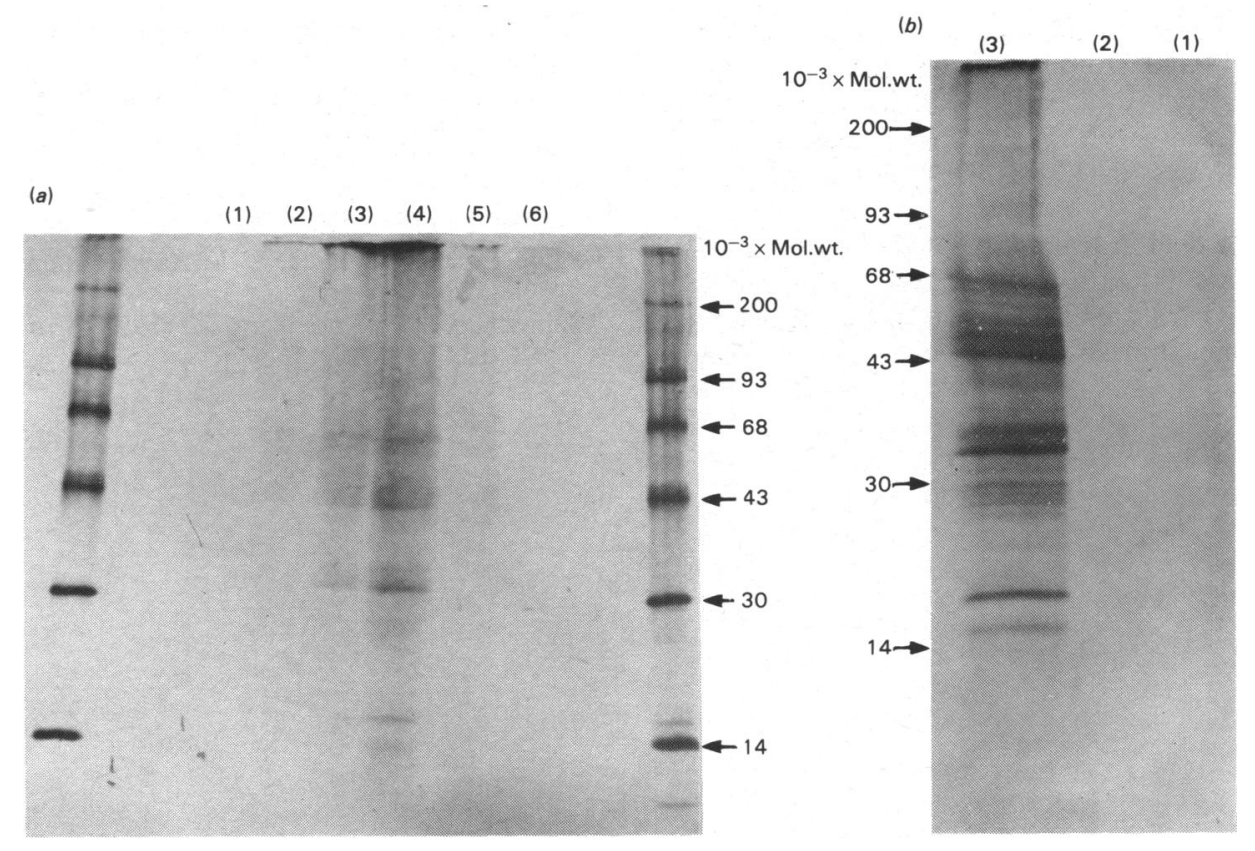

Fig. 2. SDS/polyacrylamide-gel-electrophoretic analysis of (a) time-course study of Ret-P mediated transfer to endogenous acceptors and $(b)$ endogenous acceptors of $\left[{ }^{14} \mathrm{C}\right]$ mannose from $G D P-\left[{ }^{14} C\right]$ mannose in incubations containing Ret-P and $p$ Ret-P

(a) $\left[{ }^{14} \mathrm{C}\right]$ Mannose-labelled acceptors were prepared from incubations of rat liver microsomes containing $500 \mu \mathrm{g}$ of microsomal protein and the usual incubation mixture. Incubations (1)-(5) contained $1 \mu \mathrm{Ci}$ each of $\mathrm{GDP}$-[ $\left.{ }^{14} \mathrm{C}\right]$ mannose $(25 \mu \mathrm{M})$, whereas incubation (6) contained $1 \mu \mathrm{Ci}$ of $\left[{ }^{14} \mathrm{C}\right]$ mannose. Incubations (1), (2), (3), (4) and (6) contained Ret-P $(0.15 \mathrm{~mm})$. Incubations were run at $37^{\circ} \mathrm{C}$ for the following times: (1), for $5 \mathrm{~min}$; (2), for $30 \mathrm{~min}$; (3), for $60 \mathrm{~min}$; (4), (5) and (6) for $3 \mathrm{~h}$. They were terminated by adding $15 \mathrm{vol}$. of chloroform $/ \mathrm{methanol}(2: 1, \mathrm{v} / \mathrm{v})$. The denatured pellets were washed twice with $1 \mathrm{ml}$ of chloroform/methanol $(2: 1, \mathrm{v} / \mathrm{v})$, twice with water and twice with chloroform/methanol/water $(10: 10: 3$, by vol.). The residues were solubilized in $45 \mu 1$ of $10 \mathrm{M}$-urea, $15 \mu \mathrm{l}$ of $0.8 \mathrm{M}$-dithiothreitol in $10 \% \mathrm{SDS}$ and $80 \mu \mathrm{l}$ of water and heated at $95^{\circ} \mathrm{C}$ for $10 \mathrm{~min}$. The cooled solution was applied to gels for electrophoresis. Fluorographs were obtained as described by Shimatake \& Rosenberg (1981), after exposure for 34 days. (b) Incubations contained the same components as in $(a)$ and proceeded at $37^{\circ} \mathrm{C}$ for $60 \mathrm{~min}$. Incubation (1) had no Ret-P; incubation (2) contained $10 \mu \mathrm{g}$ of pRet- $P$ and incubation (3) contained $10 \mu \mathrm{g}$ of Ret-P. After incubation the reaction was stopped with $15 \mathrm{vol}$. of chloroform/methanol $(2: 1, \mathrm{v} / \mathrm{v})$. The denatured residue was washed twice with $1 \mathrm{ml}$ of chloroform/methanol $(2: 1, \mathrm{v} / \mathrm{v})$, three times with $1 \mathrm{ml}$ of water and three times with $1 \mathrm{ml}$ of chloroform/methanol/water $(10: 10: 3$, by vol.). The resulting denatured pellet was suspended in $45 \mu 1$ of $10 \mathrm{M}$-urea, $15 \mu \mathrm{l}$ of $0.8 \mathrm{M}$-DTT in $10 \% \mathrm{SDS}$ and $80 \mu \mathrm{l}$ of water and heated at $95^{\circ} \mathrm{C}$ for 10 min. Equivalent amounts of protein $(400 \mu \mathrm{g})$ were applied to the gel: 7600 c.p.m. was applied to (1); 5400 c.p.m. to (2); 31870 c.p.m. to (3). Fluorographs were obtained as described in $(a)$. 
(results not shown) Ret- $P$ was inactive in significantly stimulating the incorporation of mannose into the chloroform/methanol/water extract, which contains most of the lipid-oligosaccharide derivatives (Fig. 1). Ret- $P$ but not pRet- $P$ stimulated transfer to protein (Fig. 1).

SDS/polyacrylamide-gel-electrophoretic analyses of endogenous rat liver microsomal acceptors (Fig. $2 a$ ) show labelled prominent bands at mol.wts. about $17000,33000,45000$ and 65000 from incubations containing Ret $P$. The fluorograph shows a timedependence with maximal labelling at $3 \mathrm{~h}$. It also shows very little labelling in incubations without Ret- $P$ (lane 5) or containing $1 \mu \mathrm{Ci}$ of $\left[{ }^{14} \mathrm{C}\right.$ lmannose instead of GDP-[ $\left.{ }^{14} \mathrm{C}\right]$ mannose (lane 6). Fig. 2(b) shows a similar experiment with prominent labelling in the incubations containing Ret- $P$, but not pRet- $P$.

Labelled bands from Ret- $P$-containing incubations were not detected at mol.wt. higher than 14000 after treatment with Pronase (Y. Shidoji, C. S. Silverman-Jones \& L. M. De Luca, unpublished work).

The data demonstrate that saturation of the sidechain double bonds of Ret- $P$ destroys its activity in mannosyl transfer to protein, in the presence of pRet-P-Man synthesis.
We thank Ms. Maxine Bellman and Ms. Margaret Green for typing the manuscript.

\section{References}

Bhat, P. V., De Luca, L. M. \& Wind, M. L. (1980) Anal. Biochem. 102, 243

Chen, D. S., Toribara, T. Y. \& Warner, H. (1956) Anal. Chem. 28, 1756-1758

De Luca, L. M. (1977) Vitam. Hor. (N.Y.) 35, 1-57

De Luca, L. M., Frot-Coutaz, J. P., Silverman-Jones, C. S. \& Roller, P. R. (1977) J. Biol. Chem. 252, 2575

De Luca, L. M., Brugh, M. R., Silverman-Jones, C. S. \& Shidoji, Y. (1982) Biochem. J. in the press

Frot-Coutaz, J. P., Silverman-Jones, C. S. \& De Luca, L. M. (1976) J. Lipid Res. 17, 200

Laemmli, W. (1970) Nature (London) 227, 680

Lowry, O. H. Rosebrough, N. J., Farr, A. L. \& Randall, R. J. (1951) J. Biol. Chem. 193, 265-275

Rosso, G. Chi, De Luca, L. M., Warren, C. D. \& Wolf, G. (1975) J. Lipid Res. 16, 235-243

Shidoji, Y. \& De Luca, L. M. (1981) Biochem. J. 200, 529-538

Shimatake, H. \& Rosenberg, M. (1981) Nature (London) 292, 128 